\title{
Correction to: Evaluation of improved cassava genotypes for yield and related traits for a better breeding strategy under different agroecologies in Nigeria
}

\author{
N. A. Adetoro - O. O. Oworu - A. L. Nassir - A. Bello - E. Parkes \\ S. A. Ogunbayo - M. G. Akinwale - O. O. Aina - A. Afolabi - P. Iluebbey \\ L. O. Sanni - B. Maziya-Dixon - A. Dixon - P. Kulakow
}

Published online: 26 May 2021

(C) The Author(s) 2021

Correction to: Euphytica (2021) 217:73

https://doi.org/10.1007/s10681-021-02798-9

In the above mentioned publication, the funding information and the acknowledgement section was incomplete. The original article has been corrected and the final text is also published here:

Acknowledgements The authors thank the UK's Foreign, Commonwealth \& Development Office (FCDO) and the Bill \& Melinda Gates Foundation (Grant INV-007637 http://www. gatesfoundation.org) for their financial support. Also the
Cassava Breeding and Biochemistry units of the International Institute of Tropical Agriculture, Ibadan, Nigeria.

Funding The research was financially supported by the UK's Foreign, Commonwealth \& Development Office (FCDO) and the Bill \& Melinda Gates Foundation (Grant INV-007637 http:// www.gatesfoundation.org).

Publisher's Note Springer Nature remains neutral with regard to jurisdictional claims in published maps and institutional affiliations.

The original article can be found online at https:// doi.org/10.1007/s10681-021-02798-9.

N. A. Adetoro $(\bowtie) \cdot$ A. Bello $\cdot$ E. Parkes

S. A. Ogunbayo - M. G. Akinwale .

O. O. Aina - A. Afolabi · P. Iluebbey ·

L. O. Sanni - B. Maziya-Dixon · A. Dixon · P. Kulakow International Institute of Tropical Agriculture (IITA), PMB 5320, Ibadan, Oyo State, Nigeria

e-mail: n.adetoro@cgiar.org 